\section{Efficacy and Cost of Cultivators, Steam, or an Organic Herbicide for Weed Control in Organic Vineyards in the San Joaquin Valley of California}

\author{
Anil Shrestha ${ }^{1,5}$, S. Kaan Kurtural ${ }^{2}$, Matthew W. Fidelibus ${ }^{3}$, \\ Geoffrey Dervishian ${ }^{2}$, and Srinivasa Konduru ${ }^{4}$
}

ADDITIONAL INDEX WORDs. mechanical weed control, raisin grape, wine grape

SUMMARY. Weed management is an important problem faced by organic grape (Vitis vinifera) growers as there are few effective and economic options available.

However, new organically acceptable weed control products have become available in recent years. Several studies were conducted to compare the efficacy of two mechanical weed control methods (French plow and Bezzerides tree and vine cultivator) with steam, and an organic herbicide (d-limonene) in organic raisin and wine grape vineyards. The experiments were designed as split plots with the aforementioned treatments as main plots with additional weed control treatments (handhoeing and no handhoeing in the raisin grape vineyards; hoeing, no hoeing, steam, and d-limonene in the wine grape vineyard) one month after the main plot treatment as subplots. The plow provided the greatest level of weed control among the treatments followed by the cultivator. The time required to hoe mechanically cultivated plots was also generally lower than the other treatments. Steam and herbicide only suppressed weeds for 2-3 weeks, and the time needed to hoe plots in these treatments was generally similar to the untreated control at all sampling dates. The mechanical treatments also were two to four times more cost-effective than steam or herbicide. Therefore, mechanical treatments were the most effective and economical weed control methods, though none of the treatments affected vine growth, midday stem water potential, petiole nitrate concentration at bloom, grape yield, or quality.

$\mathrm{M}$ arket forces and environmental considerations have encouraged some California grape growers to adopt organic management practices. In 2008 , there were an estimated 23,000 acres of organic vineyards statewide (Klonsky,

The article was funded by the California Agricultural Research Initiative (Project No. 11-01-006), Propane Education and Research Council, The California Raisin Marketing Board, Viticulture Consortium West, and the Bronco Wine Company Viticulture Research Chair Trust Funds.

The authors thank the Sunmaid Growers Association, Steve Fukugawa, and Western Coast Grape Farming for their cooperation. The assistance of staff and students Jorge Aguilar, Sara Alatorre, Andrew Beebe, Kimberley Cathline, Jeffrey Gallagher, Marcelo Moretti, Nathalia Moretti, Katrina Steinhauer, Dave Terry, and Murilo Triano is also gratefully acknowledged.

${ }^{1}$ Department of Plant Science, 2415 East San Ramon Avenue M/S AS 72, California State University, Fresno, CA 93740

${ }^{2}$ Department of Viticulture and Enology, 2360 East Barstow Avenue M/S VR 89, California State University, Fresno, CA 93740

${ }^{3}$ Department of Viticulture and Enology, University of California, Davis, CA 95616

${ }^{4}$ Department of Agricultural Business, 2415 East San Ramon Avenue M/S AS 72, California State University, Fresno, CA 93740

${ }^{5}$ Corresponding author. E-mail: ashrestha@csufresno. edu.
2010). Weed management during the transition from conventional to organic farming presents agronomic (Barberi 2002; Bond and Grundy, 2001; Ngouajio and McGiffen, 2002; Smith et al., 2009) and economic (Park and Lohr, 2005) challenges to grape growers. This transition period is marked by an increase in weed populations when the transition is managed by growers who are accustomed to using synthetic herbicides to control weeds (Martini et al., 2004). Few organically acceptable herbicides have been shown to be efficacious, reliable, and economical (Capps and Lanini, 2008). In recent years, some organic herbicides have been registered; however, their efficiency and cost-effectiveness in comparison with other weed control methods has not been directly compared.

Mechanical cultivation has long been known to be an effective weed management practice, but it can generate dust, a regulatory issue [particulate matter (PM10)] in the San Joaquin Valley (SJV) of California, and depending on the terrain, wind, and rainfall or irrigation pattern, may also accelerate soil erosion (Gago et al., 2007). Handhoeing is another potentially effective weed management practice, though it is prohibitively laborious and expensive. Other examples of alternative weed management practices include the use of steam (Kolberg and Wiles, 2002; Shrestha et al., 2004, 2012), flame (Ascard 1998; Ullao et al., 2010), microwaves (Sartorato et al., 2006) reduced soil disturbance cultivators, cover crops, and mulches (Mennan and Ngouajio, 2012). Each of these tools has specific limitations in vineyards and other cropping systems. For example, Shrestha et al. (2012) reported that steam, propane flaming, and an organic herbicide (d-limonene) provided 3 to 6 weeks of weed suppression in nonbearing almond (Prunus dulcis) orchards. Thus, repeated applications of these

\begin{tabular}{|c|c|c|c|}
\hline $\begin{array}{l}\text { Units } \\
\text { To convert U.S. to SI, } \\
\text { multiply by }\end{array}$ & U.S. unit & SI unit & $\begin{array}{l}\text { To convert SI to U.S., } \\
\text { multiply by }\end{array}$ \\
\hline 0.4047 & $\operatorname{acre}(\mathrm{s})$ & ha & 2.4711 \\
\hline 102.7902 & acre-inch $(e s)$ & $\mathrm{m}^{3}$ & 0.0097 \\
\hline 0.1 & bar & $\mathrm{MPa}$ & 10 \\
\hline 29.5735 & $\mathrm{fl} \mathrm{oz}$ & $\mathrm{mL}$ & 0.0338 \\
\hline 0.3048 & $\mathrm{ft}$ & $\mathrm{m}$ & 3.2808 \\
\hline 0.0929 & $\mathrm{ft}^{2}$ & $\mathrm{~m}^{2}$ & 10.7639 \\
\hline 3.7854 & gal & $\mathrm{L}$ & 0.2642 \\
\hline 9.3540 & $\mathrm{gal} / \mathrm{acre}$ & $\mathrm{L} \cdot \mathrm{ha}^{-1}$ & 0.1069 \\
\hline 2.54 & inch(es) & $\mathrm{cm}$ & 0.3937 \\
\hline 0.4536 & $\mathrm{lb}$ & $\mathrm{kg}$ & 2.2046 \\
\hline 4.8824 & $\mathrm{lb} / \mathrm{ft}^{2}$ & $\mathrm{~kg} \cdot \mathrm{m}^{-2}$ & 0.2048 \\
\hline 1.6093 & $\mathrm{mph}$ & $\mathrm{km} \cdot \mathrm{h}^{-1}$ & 0.6214 \\
\hline 305.1517 & $\mathrm{oz} / \mathrm{ft}^{2}$ & $\mathrm{~g} \cdot \mathrm{m}^{-2}$ & 0.0033 \\
\hline 1 & ppm & $\mathrm{mg} \cdot \mathrm{L}^{-1}$ & 1 \\
\hline 1 & ppm & $\mu \mathrm{g} \cdot \mathrm{g}^{-1}$ & 1 \\
\hline 6.8948 & psi & $\mathrm{kPa}$ & 0.1450 \\
\hline 2.2417 & ton/acre & $\mathrm{Mg} \cdot \mathrm{ha}^{-1}$ & 0.4461 \\
\hline$\left({ }^{\circ} \mathrm{F}-32\right) \div 1.8$ & ${ }^{\circ} \mathrm{F}$ & ${ }^{\circ} \mathrm{C}$ & $\left({ }^{\circ} \mathrm{C} \times 1.8\right)+32$ \\
\hline
\end{tabular}

Hortlechnology $\cdot$ February 2013 23(1) 
treatments were necessary, which may not be cost-effective. McCue and Schupp (1991) observed limited success with rotary tillage for in-row weed management in apple (Malus $\times$ domestica) orchards. Baumgartner et al. (2007) suggested that more than two passes with a Clemens cultivator may be required to reduce weed biomass to levels comparable with that obtained by glyphosate, a synthetic herbicide.

In-row cover crops have been successfully used in orchards and vineyards in several areas. Mennan and Ngouajio (2012) found that brassica (Brassica sp.) cover crops provided season-long weed control, and a mulch of hazelnut (Corylus avellana) husks provided upto six months of weed suppression in hazelnut orchards. Similarly, Steinmaus et al. (2008) showed that mulched cover crops provided similar or greater weed control than tillage or synthetic herbicides in northern California vineyards. Elmore et al. (1997) also found benefits of cover crop mulches in weed suppression in vineyards in central California, although Fredrikson et al. (2011) suggested that cover crop residue of 2.5 to $15 \mathrm{~kg} \cdot \mathrm{m}^{-2}$ was required to provide effective in-row weed control in vineyards in western Oregon. However, cover crops in the SJV are mostly limited to winter annuals because of restrictions imposed by the climate and cultural practices (Hirschfelt, 2000).

The efficacy and cost-effectiveness of many of the alternative weed management practices discussed earlier can also vary from one region to another and among various grape commodities. For example, perennial cover crops that are suitable for wine grape vineyards are not suitable for traditional raisin vineyards since they would be destroyed by the soil preparations needed to facilitate grape drying (Hirschfelt, 2000). Hence, organic weed control practices need to be evaluated in the SJV to determine whether they are suited to local conditions and if they are cost-effective. Therefore, the objective of this study was to compare the efficacy and costeffectiveness of various weed control methods and their impacts on crop yield and quality in organic raisin and wine grape vineyards in the SJV.

\section{Materials and methods}

Experiments were conducted in 2010 and 2011 in commercial raisin and wine grape vineyards in the SJV. Details of the vineyards and the experimental treatments are as follows:

RAISIN GRAPE VINEYARD STUDIES. Studies were conducted in two 'Thompson Seedless' raisin grape vineyards near Selma, CA (lat. 36 $32^{\prime}$ $51^{\prime \prime} \mathrm{N}$, long. $\left.119^{\circ} 34^{\prime} 42^{\prime \prime} \mathrm{W}\right)$ and Kingsburg, CA (lat. $36^{\circ} 28^{\prime} 52^{\prime \prime} \mathrm{N}$, long. $119^{\circ} 34^{\prime} 40^{\prime \prime} \mathrm{W}$ ) in 2010 and 2011 , respectively. The soil type in both these vineyards was a coarseloamy, mixed, superactive, thermic Typic Xerorthents. Vines in both vineyards were head-trained, canepruned, and supported by single-wire trellis systems. Vine rows were $12 \mathrm{ft}$ apart, and in-row vine spacing was $7 \mathrm{ft}$ in the Selma vineyard in 2010 and $8 \mathrm{ft}$ in the Kingsburg vineyard in 2011 , with all vines planted on $1-\mathrm{ft}$ tall raised berms. Vines in the Selma vineyard were drip irrigated, receiving between 48 and 54 gal of water per vine each week during the summer, whereas vines in the Kingsburg vineyard were flood irrigated, receiving five applications of 6-to 8-acre-inches of water over the growing season. These irrigation regimes followed the grower's normal practices at these sites and are within a range considered normal and ordinary for raisin grape production in the SJV. No fertilizer was applied in either vineyard for the past several years. Weed control treatments in 2010 included: a nontreated control, Bezzerides tree and vine cultivator (Bezzerides Brothers, Orosi, CA), French plow (L\&H Maunufacturing, Selma, CA), organic herbicide $\left[\mathrm{d}\right.$-limonene (GreenMatch ${ }^{\circledR}$; Marrone Bio Innovations, Davis, CA)], and steam (Batchen Stinger; D.J. Batchen, Auburn, Australia). These treatments are hereafter referred to as cultivator, plow, herbicide, and steam, respectively. The experimental design was a randomized complete block arranged as a split plot with four replications where the treatments mentioned earlier were the main plots and handhoeing or no handhoeing was the split plot. Each main plot, except the steam treatment plots, consisted of eight vines. The steam treatment plots consisted of 10 vines to facilitate the use of the steaming machine. A three-vine buffer space was maintained between each main plot. Each main plot was divided into two five-vine subplots with the three middle vines in each subplot designated for data collection, and the two outer vines maintained as buffers. The experimental design and treatments were similar in 2011. The steam generating machine was equipped with a propane-powered burner that combusted propane and delivered steam through an adjustable sidearm (canopy). More details of the machine are available in Shrestha et al. (2012). The machine was pulled by a tractor at a travel speed of $1.5 \mathrm{mph}$. The steam discharging arm was adjusted to 18 inches away from the main body and angled $30^{\circ}$ away from the vine row. The height of the arm was set so that the bottom of the arm from where the steam was discharged was 6 inches above the ground. One pass was made with the machine on each side of the vine row. The treated strip was about 18 inches wide on either side of the vine row. The herbicide d-limonene $\left(\right.$ GreenMatch ${ }^{\circledR}$ ) was applied at $6.6 \mathrm{gal} / \mathrm{acre}$ a.i. with a carbon dioxide-pressurized backpack sprayer (R \& D Sprayers; Bellspray, Opelousas, LA) calibrated to deliver $60 \mathrm{gal} /$ acre at 22 psi. A nonionic surfactant (Nu Film-P; Miller Chemical and Fertilizer, Hanover, PA) labeled for use in organic cropping systems was added at $1 \% \mathrm{v} / \mathrm{v}$. A two-nozzle sprayer boom equipped with Turbo Twinjet 8004 nozzles (Teejet Technologies, Wheaton, IL) spaced 20 inches apart was used. One 3-ft-wide pass was made between two vines in a row at a travel speed of $1.3 \mathrm{mph}$. The plow and the cultivator were operated with a tractor at $\approx 2 \mathrm{mph}$ and an 18-inch-wide pass on both sides of the vine row was made. About 6 weeks after treatment (WAT), in the plow plots, the berms were rebuilt with a tandem disc. The subplot treatments were implemented by handhoeing one half of the plot and leaving the other half nonhoed $\approx 4$ and 6 weeks after application of the main-plot treatments (Table 1) in 2010 and 2011, respectively. The hoeing was done on 18-inch-wide strips on either side of the vine and the time taken to hoe each subplot was recorded.

WINE GRAPE VINEYARD STUDIES. The wine grape vineyard in both years of the study was located near Madera, CA (lat. $36^{\circ} 52^{\prime} 48^{\prime \prime} \mathrm{N}$, long. $120^{\circ} 09^{\prime}$ $\left.57^{\prime \prime} \mathrm{W}\right)$. The soil type in this vineyard was a fine, mixed, active, thermic Abruptic Durixeralfs. This vineyard was established in 2007 with 'Pinot 
Table 1. Dates of treatment applications and samplings in the raisin grape and wine grape vineyard experiments in 2010 and 2011.

\begin{tabular}{|c|c|c|c|c|}
\hline \multirow[b]{2}{*}{ Operation } & \multicolumn{2}{|c|}{ Raisin grape vineyard } & \multicolumn{2}{|c|}{ Wine grape vineyard } \\
\hline & 2010 & 2011 & 2010 & 2011 \\
\hline Main-plot treatment application & 9 Mar. & 5 Mar. & 18 Mar. & 18 Mar. \\
\hline First weed biomass sampling & 10 Apr. & 19 Apr. & 27 Apr. & 10 May \\
\hline $\begin{array}{l}\text { Subplot treatment application } \\
\text { and first handhoeing }\end{array}$ & 10 Apr. & 19 Apr. & 27 Apr. & 12 May \\
\hline Grapevine petiole sampling & 19 May & I June & 27 May & 2 June \\
\hline Second weed biomass sampling & 3 June & 13 June & 27 May & 14 June \\
\hline First water potential measurement & 16 July & 13 June & 20 July & 14 June \\
\hline Second water potential measurement & 12 Aug. & I July & 11 Aug. & 14 July \\
\hline Second handhoeing & - & 1 July & - & 30 June \\
\hline Leaf area sampling and shoot counts & 15 June & I July & 24 June & 28 June \\
\hline Final weed biomass sampling & 9 Sept. & 5 Aug. & 12 Aug. & 8 Aug. \\
\hline $\begin{array}{l}\text { Grape berry sampling for quality } \\
\text { analysis }\end{array}$ & 11 Sept. & 7 Sept. & 11 Aug. & 15 Aug. \\
\hline Grape harvest and yield determination & 11 Sept. & 14 Sept. & 19 Aug. & 15 Aug. \\
\hline
\end{tabular}

Gris 03 ' on 1103P rootstock. Vines were trained to a bilateral cordon 54 inches above vineyard floor with two foliage support wires at 62 inches on a 10 -inch t-top. The vineyard was drip irrigated with pressure-compensating emitters spaced at 38 inches delivering $0.5 \mathrm{gal} / \mathrm{h}$ per emitter. No fertilizer was applied in either year of the study. Weed control treatments included: a nontreated control, cultivator, herbicide, and steam. The experimental design was a randomized complete block arranged as a split plot with four replications, where the treatments mentioned earlier were the main plots and a second application of steam, second application of herbicide, or hoeing or no hoeing was the split-plot treatment. The vine rows were spaced $11 \mathrm{ft}$ apart and the in-row vine spacing was $7 \mathrm{ft}$. Vine rows were not on raised berms as in the raisin vineyards, and the plow treatment was not included in this vineyard. Each main plot consisted of 16 vines. A buffer space of three vines was maintained between each main plot. The main plots were divided into four equal plots for the subplot treatments. Thus, each subplot consisted of four vines and the two middle vines in each subplot were designated for data collection and the two outer vines were maintained as buffers. Treatment application details for steam, herbicide, and cultivator were similar to that as in the raisin vineyards (Table 1 ). About 7 weeks after the application of the main-plot treatments, the subplot treatments were imposed. Treatment application methods for steam and herbicide in the subplots were kept similar to the main plots as described earlier. One subplot was left nonweeded. The hoeing was done on 18-inch-wide strips on either side of the vine. Time taken to hoe the area between two vines (3-ft-wide rows only) in each subplot was recorded, and hoeing time per acre was estimated by multiplying this value by the estimated number of vines/acre (518 and 454 vines/acre in 2010 and 2011 , respectively). The hoed subplots were hoed again $\approx 10$ weeks after the first hoeing (Table 1 ).

WEED CONTROL EVALUATIONS. In both vineyard types and in both years of the study, weed control estimates were made at weekly intervals for 4 weeks after each main-plot treatment. The weed control estimates were based on percentage of plant appearing necrotic compared with the untreated plots in each replication. A $0 \%$ to $100 \%$ scale was used where $0 \%$ meant no necrosis was observed on the plants and $100 \%$ meant the plants were dead. Weed biomass was assessed three times (Table 1) during the growing season by randomly placing a $0.25-\mathrm{m}^{2}$ polyvinyl chloride quadrat within the treated area of each plot. The weeds were clipped at the soil surface, bagged, oven dried at $60{ }^{\circ} \mathrm{C}$ for $72 \mathrm{~h}$, and weighed. These three sampling times represented early-season, midseason, and late-season weed biomass. Plots designated for hoeing were hoed once in both study sites in 2010 and twice in 2011 (Table 1) because 2011 was comparatively wetter than 2010 early in the growing season and resulted in greater weed pressure (data not shown). The time taken to hoe each treatment plot was recorded, and hoeing time per acre was estimated as described earlier assuming 565 vines/acre.

VINE GROWTH AND CANOPY CHARACTERISTIC ASSESSMENTS. Vine growth and canopy characteristics in both vineyard types in both years of the study were assessed by taking measurements on shoot counts [as described by Terry and Kurtural (2011)], canopy leaf area, petiole nitrate $\left(\mathrm{NO}_{3}\right)$ content at bloom, and midday leaf water potential $(\Psi)$ (Table 1). Four randomly selected count-shoots in each treatment plot were destructively harvested at 1200 growing degree-days (base temperature $50^{\circ} \mathrm{F}$ ). Shoots were placed in plastic bags, sealed, and kept in storage in a refrigerator and measurements were taken within 24 h. Shoots were separated into main and lateral axes. Leaf area of individual samples was measured using a leaf area meter (LI-3000; LI-COR, Lincoln, NE). The number of leaves for each axis was counted. Total leaf area for each shoot was calculated as described by Keller et al. (2008). The leaf area:fruit ratio was calculated by dividing the canopy leaf area by the crop weight collected from that single treatment replicate. Calculations for the canopy microclimate variables such as percent light interception, leafiness index, shoots per acre, distance between shoots, and leaf layer number was determined according to the methods of Smart (1985). Vine nutritional status ( $\mathrm{NO}_{3}$ concentration) was assessed by analyzing $\mathrm{NO}_{3}$ in petioles opposite clusters at bloom (Christensen et al., 1982). The petioles were ground in a Wiley mill and $\mathrm{NO}_{3}$ concentration in the samples was determined using an automated discrete analyzer (Seal AQ2; Seal Analytical, Mequon, WI). The midday $\Psi$ was measured at solar noon at veraison and harvest, on four fully expanded sun leaves per data vine with a Scholander type pressure chamber (model 610 pressure chamber instrument; PMS Instrument, Corvallis, OR).

YIELD, YIELD COMPONENTS, AND FRUIT COMPOSITION. Fruit were harvested by hand at commercial ripeness (Table 1), at which time yield and cluster numbers were determined. Average cluster weight was calculated by 
dividing fruit yield by the number of clusters harvested. Before harvest, a 100-berry sample was collected from each plot, weighed, and average berry weight determined. The berries were then crushed by hand and a $5-\mathrm{mL}$ portion of each sample was used to determine the percent total soluble solids (TSS) using a digital refractometer (Spec Scientific, Scottsdale, AZ). Juice $\mathrm{pH}$ was determined with a $\mathrm{pH}$ meter (model ARl 5; Fisher Scientific, Pittsburgh, PA), and the titratable acidity of each sample was determined by titrating to $\mathrm{pH} 8.2$ with $0.1 \mathrm{~N}$ sodium hydroxide and expressed as grams per liter. Raisin grapes were harvested when TSS met or exceeded $20 \%$. Clusters of fruit were picked from the vine by hand and laid on paper trays between the vine rows to dry. When raisins dried to $\approx 14 \%$ moisture, all the raisins in each plot were collected, weighed, mixed, and a 2-lb subsample from each plot was placed in a polyethylene bag and submitted to the U.S. Department of Agriculture (USDA) Processed Products Division, Fresno, CA. Trained USDA inspectors determined quality grades and moisture content using industry standard methods (Kagawa, 2000). Random variation in raisin moisture content may affect the analysis of yield data, so the weights were standardized to $14 \%$ moisture for statistical comparisons of yield (Fidelibus et al., 2007). Pruning weights were measured during the winter dormancy period only in the raisin grape vineyards.

Cost analysis. A comparative cost analysis of each treatment was conducted based on the methods and costs reported by Verdegaal et al. (2012). The time to apply each treatment and the follow-up labor was measured by timing similar laborers in 2010 and 2011 in each treatment replicate. The time to accomplish each weed control pass was then divided by the number of vines in the four treatment replicates measured, then the labor hours and cost per acre were calculated by multiplying the time and cost per vine by the number of vines per acre. A cost per vine to accomplish each task was calculated, multiplied by the appropriate labor and benefit rate and labor cost per acre was calculated by multiplying the resultant costs by the number of vines per acre. As per the practice followed in this crop budget, the labor costs involving machinery included an extra $20 \%$ to account for labor involved in equipment setup, moving, etc., and tractor costs included an extra $10 \%$ to account for setup, travel, and downtime. Propane cost $(\$ 2.75 / \mathrm{gal})$ for the steam machine and herbicide cost (d-limonene, \$37/gal) were the actual retail prices. However, application cost for the herbicide was based on a tractor-mounted sprayer to match the reality of farm operations in California. It was assumed that it took $26 \mathrm{~min} /$ acre for herbicide application (Verdegaal, et al., 2012). This timing was multiplied by the operating costs of a 30-horsepower four-wheel-drive tractor $(\$ 7 / \mathrm{h})$ and a 200 -gal sprayer $(\$ 0.6 / \mathrm{h})$ to obtain the cost of herbicide application with a tractor-mounted sprayer. The analysis did not take into account any cash and noncash overhead costs, including depreciation as necessary information about equipment such as steam machine was not available.

Data Analysis. Data for all parameters were tested to verify if the assumptions of analysis of variance (ANOVA) were met. Data which failed to meet the assumptions of ANOVA were $\log 10$ transformed and analyzed using general linear model procedure in SAS (version 9.2; SAS Institute, Cary, NC). The significance level was set at 0.05 and means were separated using Fisher's protected least significant difference test. For the transformed data, when the ANOVA showed significant differences, the mean separation test was conducted on the transformed data but nontransformed means are presented. Interactions between year and treatments were tested in each vineyard and, whenever these interactions were significant $(P<0.05)$, analysis was conducted separately for each year.

\section{Results and discussion Weed control evaluations}

EFFECTS OF MAIN-PLOT TREATMENTS. Weed control in the vineyards depended on the year, the main- and subplot treatments, and the interactions between the mainand subplots. Therefore, data were analyzed separately for each year and vineyard (raisin or wine grape). Since the subplot treatments were applied almost one month after application of the main-plot treatments, observations made before the subplot treatments were considered sole effects of the main plot and are discussed first (Table 2). This is followed by a discussion of the interaction effects of the main- and subplot treatments, which were noted later in the season (Figs. 1-4).

MaIN-PLOT EFFECTs. The major weed species at the time of the mainplot treatment applications in the 2010 raisin vineyard were annual bluegrass (Poa annua), redmaids (Calandrinia ciliata), henbit (Lamium amplexicaule), common chickweed (Stelaria media), horseweed (Conyza canadensis), shepherdspurse (Capsella bursa-pastoris), and coast fiddleneck (Amsinckia menziessi). At each weekly evaluation, the plowed plots provided the greatest weed control in 2010 (Table 2). The plow uprooted and buried all the weeds except for a few plants at the base of the vines. However, although data were not recorded, this implement caused extensive soil disturbance and was often observed to injure grapevine roots. The cultivator provided the second most effective weed control treatment in 2010 (Table 2). This implement undercut the weeds but did not necessarily invert them, so some weeds, such as annual bluegrass, occasionally reestablished where root-soil contact and adequate moisture were present. Therefore, the cultivator was not as effective as the plow, but it was less disruptive to the soil and the vine roots.

In 2010 , the herbicide treatment provided upto $70 \%$ weed control 1 week after application (Table 2). However, the effects did not last more than 3 weeks and most of the weeds had regrown by 4 WAT. Most of the weed species mentioned earlier are winter annuals and were at an advanced stage of growth; weed biomass at the time of treatment application ranged from 228 to $560 \mathrm{~g} \cdot \mathrm{m}^{-2}$, which could have reduced herbicide efficacy. The steam treatment was among the least effective control measures tested, lasting only about 2 weeks (Table 2 ). The advanced growth stage of the weeds at the time of treatment may also have contributed to the poor control with steam. However, most of the younger weeds also regrew within a few weeks. These results support other recent findings suggesting that steam has differential effects on various weed species, with succulent weeds and grasses being 
Table 2. Weekly estimates of percent weed control in the main plots after the initial treatment, total aboveground weed biomass 4 weeks after treatment (WAT), and average handhoeing 4 WAT in the raisin grape and wine grape vineyards in the southern San Joaquin Valley of California in 2010 and $2011(n=4)$.

\begin{tabular}{|c|c|c|c|c|c|c|}
\hline \multirow[b]{2}{*}{ Yr and main-plot treatment ${ }^{\mathrm{z}}$} & \multicolumn{4}{|c|}{ Weed control $(\%)^{\mathrm{y}}$} & \multirow{2}{*}{$\begin{array}{c}\begin{array}{c}\text { Total aboveground } \\
\text { weed biomass }\end{array} \\
\left(\mathrm{g} \cdot \mathrm{m}^{-2}\right)^{\mathrm{x}}\end{array}$} & \multirow{2}{*}{$\begin{array}{r}\begin{array}{r}\text { Total hand } \\
\text { weeding tim }\end{array} \\
\text { (h/acre per per }\end{array}$} \\
\hline & 1 WAT & 2 WAT & 3 WAT & $4 \mathrm{WAT}$ & & \\
\hline \multicolumn{7}{|l|}{ Raisin grape vineyards } \\
\hline \multicolumn{7}{|l|}{2010} \\
\hline Nontreated control & $0 \mathrm{e}^{\mathrm{w}}$ & $0 \mathrm{e}$ & $0 \mathrm{~d}$ & $0 \mathrm{~d}$ & $96.1 \mathrm{a}$ & $10.55 \mathrm{a}$ \\
\hline Cultivator & $80 \mathrm{~b}$ & $75 \mathrm{~b}$ & $73 \mathrm{~b}$ & $70 \mathrm{~b}$ & $9.8 \mathrm{c}$ & $4.23 \mathrm{c}$ \\
\hline Plow & $98 \mathrm{a}$ & $94 \mathrm{a}$ & $91 \mathrm{a}$ & $89 \mathrm{a}$ & $1.6 \mathrm{c}$ & $2.53 \mathrm{~d}$ \\
\hline Herbicide & $70 \mathrm{c}$ & $60 c$ & $45 \mathrm{c}$ & $15 \mathrm{c}$ & $37.0 \mathrm{~b}$ & $6.98 \mathrm{~b}$ \\
\hline Steam & $40 \mathrm{~d}$ & $13 \mathrm{~d}$ & $5 \mathrm{~d}$ & $0 \mathrm{~d}$ & $80.3 \mathrm{a}$ & $10.48 \mathrm{a}$ \\
\hline$P$ value & $<0.0001$ & $<0.0001$ & $<0.0001$ & $<0.0001$ & $<0.0001$ & 0.0044 \\
\hline \multicolumn{7}{|l|}{2011} \\
\hline Nontreated control & $0 \mathrm{c}$ & $0 \mathrm{c}$ & $0 \mathrm{c}$ & $0 \mathrm{c}$ & $102.9 \mathrm{a}$ & $10.45 \mathrm{ab}$ \\
\hline Cultivator & $97 \mathrm{ab}$ & $92 \mathrm{ab}$ & $84 \mathrm{a}$ & $79 \mathrm{a}$ & $24.6 \mathrm{bc}$ & $7.40 \mathrm{c}$ \\
\hline Plow & $99 \mathrm{a}$ & $99 \mathrm{a}$ & $95 \mathrm{a}$ & $94 \mathrm{a}$ & $8.6 \mathrm{c}$ & $4.63 \mathrm{c}$ \\
\hline Herbicide & $83 \mathrm{ab}$ & $65 \mathrm{~b}$ & $35 \mathrm{~b}$ & $19 \mathrm{bc}$ & $85.1 \mathrm{ab}$ & $12.88 \mathrm{a}$ \\
\hline Steam & $79 \mathrm{~b}$ & $69 \mathrm{~b}$ & $38 \mathrm{~b}$ & $21 \mathrm{~b}$ & $103.3 \mathrm{a}$ & $9.48 \mathrm{ab}$ \\
\hline$P$ value & $<0.0001$ & $<0.0001$ & $<0.0001$ & $<0.0001$ & 0.0289 & 0.0088 \\
\hline
\end{tabular}

Wine grape vineyard

2010

Nontreated control

Cultivator

Herbicide

Steam

$P$ value

2011

Nontreated control

Cultivator

Herbicide

Steam

$\begin{array}{llcc}0 \mathrm{~b} & 0 \mathrm{e} & 0 \mathrm{~d} & 0 \mathrm{~d} \\ 92 \mathrm{ab} & 80 \mathrm{a} & 73 \mathrm{a} & 64 \mathrm{a} \\ 71 \mathrm{a} & 15 \mathrm{c} & 0 \mathrm{c} & 0 \mathrm{~b} \\ 81 \mathrm{a} & 43 \mathrm{~b} & 20 \mathrm{~b} & 6 \mathrm{~b} \\ <0.0001 & <0.0001 & <0.0001 & <0.000\end{array}$

$37.3 \mathrm{a}$

$5.68 \mathrm{a}$

$6.0 \mathrm{c}$

$2.83 \mathrm{~b}$

$19.7 \mathrm{~b}$

$4.42 \mathrm{ab}$

$41.6 \mathrm{a}$

$4.97 \mathrm{a}$

0.0491

0.0050

$\begin{array}{llllrl}0 \mathrm{c} & 0 \mathrm{c} & 0 \mathrm{c} & 0 \mathrm{c} & 220.5 \mathrm{a} & 7.16 \mathrm{a} \\ 86 \mathrm{a} & 79 \mathrm{a} & 73 \mathrm{a} & 64 \mathrm{a} & 83.6 \mathrm{a} & 3.61 \mathrm{~b} \\ 78 \mathrm{a} & 53 \mathrm{~b} & 10 \mathrm{~b} & 5 \mathrm{~b} & 193.3 \mathrm{a} & 7.56 \mathrm{a} \\ 74 \mathrm{a} & 33 \mathrm{c} & 5 \mathrm{bc} & 0 \mathrm{~b} & 215.1 \mathrm{a} & 6.65 \mathrm{a} \\ <0.0001 & <0.0001 & <0.0001 & <0.0001 & 0.2175 & 0.0026\end{array}$

${ }^{\mathrm{z}}$ Untreated control $=$ no weed control treatment applied, cultivator $=$ Bezzerides tree and vine weeder $($ Bezzerides Brothers, Orosi, CA $)$, plow $=$ French plow $($ L\&H Manufacturing, Selma, CA), herbicide $=\left[\mathrm{d}\right.$-limonene $\left(\right.$ GreenMatch $^{\circledR} ;$ Marrone Bio Innovations, Davis, CA $\left.)\right]$, steam $=$ plots treated with the steaming machine $($ Batchen Stinger; D.J. Batchen, Auburn, Australia).

yercent of nontreated control.

${ }^{\mathrm{x}} \mathrm{l} \mathrm{g} \cdot \mathrm{cm}^{-2}=32.7705 \mathrm{oz} / \mathrm{ft}^{2}, \mathrm{l} \mathrm{h} /$ acre per person $=2.471 \mathrm{lh} \cdot \mathrm{ha}^{-1}$ per person.

"Means within a column followed by the same letter for each vineyard type and year are not significantly different according to Fisher's protected least significant difference test at $\alpha=0.05$.

poorly controlled compared with some other broadleaved weed species (Leon and Ferreira, 2008; Shrestha et al., 2012).

The major weed species in the 2011 raisin grape vineyard were hairy fleabane (Conyza bonariensis), horseweed, burning nettle (Urtica urens), common chickweed, annual sowthistle (Sonchus oleraceus), and common purslane (Portulaca oleracea). Most of these species were not at an advanced growth stage as in the 2010 site and the weed biomass at the time of treatment application ranged from 0 to $190 \mathrm{~g} \cdot \mathrm{m}^{-2}$. Thus, better weed control was obtained with most treatments, but the plow was still among the most effective treatments providing 94\% weed control 4 WAT (Table 2).
However, the cultivator provided similar weed control as the plow at this site. Although herbicide and steam provided better weed control in 2011 than they did in 2010 , their effects still diminished to $<70 \%$ within 2 WAT.

The success of the mechanical weed control treatments, the plow and cultivator, in the raisin vineyards was also evident from the weed biomass 4 WAT compared with the other treatments (Table 2). The low weed biomass substantially reduced the time needed to hoe those plots 4 WAT (Table 2). At 4 WAT, the herbicidetreated plots had less biomass and required less hoeing time than the untreated control in 2010 but not in 2011. The steam-treated plots were similar to the untreated control plots in both weed biomass and in the time required to hoe. These results are consistent with reports of Shrestha et al. (2012) who observed that the effects of steam and d-limonene on weed suppression did not last more than 3 to 4 WAT in an almond orchard.

The major weed species at the Madera wine grape vineyard at mainplot treatment applications were hairy fleabane, shepherd's purse, large crabgrass (Digitaria sanguinalis), cudweeds (Gnaphalium sp.), annual bluegrass, annual sowthistle, common chickweed, and redmaids. Similar to the raisin grape vineyards, the cultivator provided better weed control than the other treatments in 2010 and 
had lower weed biomass than the other treatments at 4 WAT. However, in 2011, all plots had similar weed biomass at 4 WAT (Table 2). This was probably because a heavy rain (1.67 inches) occurred $2 \mathrm{~d}$ after the cultivation treatments in 2011 . The rain may have helped some of the uprooted weeds, especially the grasses, to re-establish contact with moist soil and to regrow in the cultivator-treated plots. However, this treatment still substantially reduced hoeing time compared with the other treatments (Table 2). Although the herbicide provided upto $78 \%$ weed control I WAT, the effects diminished to $<10 \%$ by 3 WAT. Similar results were observed in the steamtreated plots where upto $81 \%$ weed control was achieved at 1 WAT diminishing to $<20 \%$ at 3 WAT (Table $2)$. These two treatments had similar weed biomass and hoeing times as the untreated control at 4 WAT.

INTERACTION EFFECTS OF MAIN AND SUBPLOT TREATMENTS. By the time the subplot treatments were applied, summer annuals had emerged and the most common weeds in the raisin vineyards in both years were hairy fleabane, horseweed, and common lambsquarters (Chenopodium album). The efficacy of the plow compared with the other treatments was still evident at the second weed biomass sampling dates, made about two months after the subplot treatments were applied (Table 1 ) in both years of the study in the raisin vineyards (Fig. 1). The cultivator was as effective as the plow in 2010 but not in

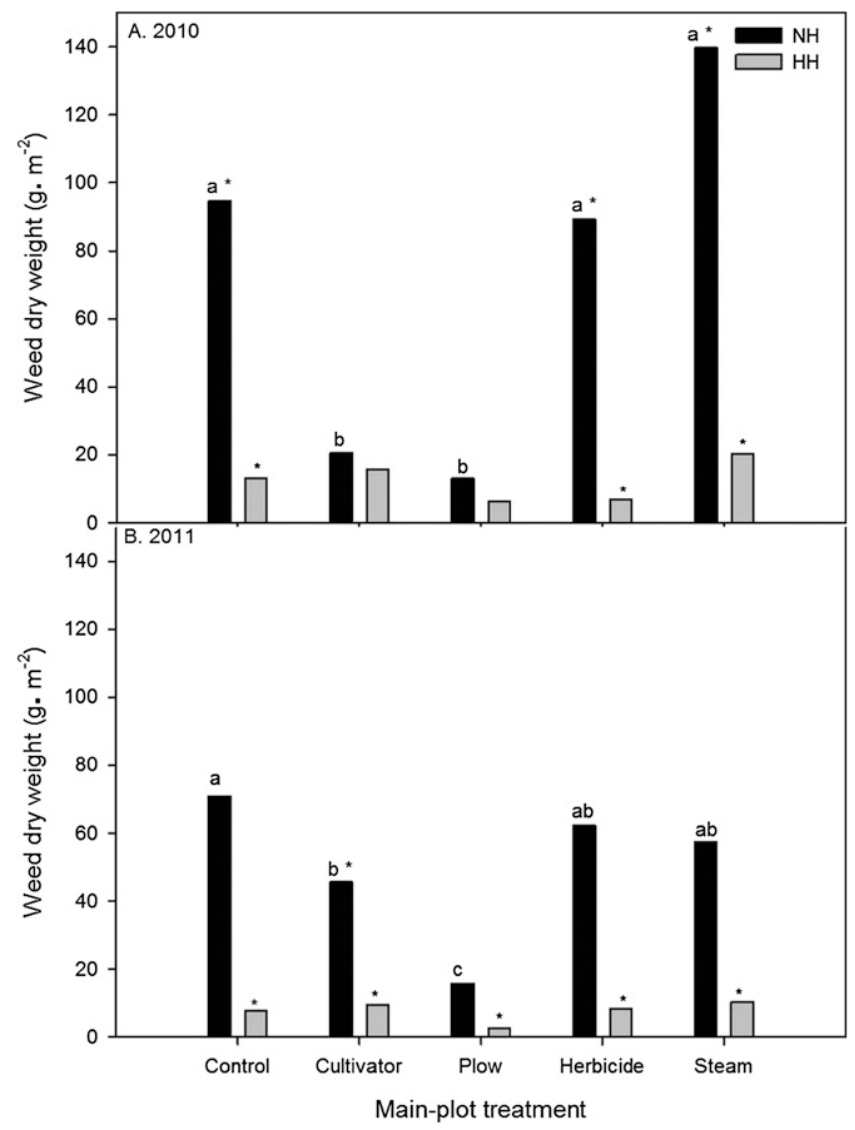

Fig. 1. Aboveground weed dry weight at the second sampling dates (Table 1 ) in the various treatments in (A) 2010 and (B) 2011 in the raisin grape vineyards in the southern San Joaquin Valley of California. Bars with the same letter are not significantly different according to Fisher's protected least significant difference test at $\alpha=0.05$. Bars with an asterisk $\left({ }^{*}\right)$ denote significant $(P<0.05)$ difference between the handhoed and non-handhoed subplots within each main-plot treatments. Analysis was conducted on $\log 10$ transformed data. Cultivator $=$ Bezzerides tree and vine weeder (Bezzerides Brothers, Orosi, CA), plow $=$ French plow (L\&H Manufacturing, Selma, CA), herbicide = [d-limonene $\left(\right.$ GreenMatch ${ }^{\circledR}$; Marrone Bio Innovations, Davis, CA)], steam = plots treated with the steaming machine (Batchen Stinger; D.J. Batchen, Auburn, Australia); $1 \mathrm{~g} \cdot \mathrm{m}^{-2}=0.0033 \mathrm{oz} / \mathrm{ft}^{2}$.

2011. This could be because the vineyard in Selma in 2011 was drip irrigated, whereas the vineyard in Kingsburg in 2011 was flood irrigated. More moisture was available on the edges of the berms in the flood than in the drip irrigated vineyard and this may have promoted more weed growth in 2011 . The other main-plot treatments had similar weed biomass as the untreated control (Fig. 1). Although weed biomass was generally lower in the hoed plots compared with the nonhoed plots, interactions occurred between the main and subplots because weed biomass was not lowered by hoeing in the plowed plots. The weed biomass in the plowed plots was already low and hoeing did not reduce the weed biomass further compared with the nonhoed plots. The weed biomass in the hoed plots was similar in all the plots regardless of the main-plot treatment (Fig. 1).

Interactions also occurred between years and main-plot treatments, and between main-and subplot treatments in the wine grape vineyard. Therefore, data were analyzed separately for each year and for main plots within the years (Fig. 2). Unlike the raisin grape vineyards, the main-plot treatments had no effect on the weed biomass at the second sampling date in either year of the study (Table 2). The subplot treatments also did not have any effect on the weed biomass except in the plots with steam as the main plot (Fig. 2). At this site, large crabgrass, green foxtail (Setaria viridis), and yellow nutsedge (Cyperus esculentus) dominated especially the plots that were cultivated and followed by hoeing (data on biomass of these individual species not shown). This treatment combination seemed to enhance the emergence and propagation of these species. Cultivation, including hoeing, can increase the population of perennial weeds such as yellow nutsedge and disperse weed propagules, as the implements can separate and/or disperse the rhizomes of this asexually propagated weed (Finney and Creamer, 2008). However, this phenomenon was not observed when steam treatment was followed by hoeing. In the steam followed by hoeing plots, hoeing reduced weed biomass more than the other subplot treatments (Fig. 2).

At the third and final sampling date, near the end of the growing 


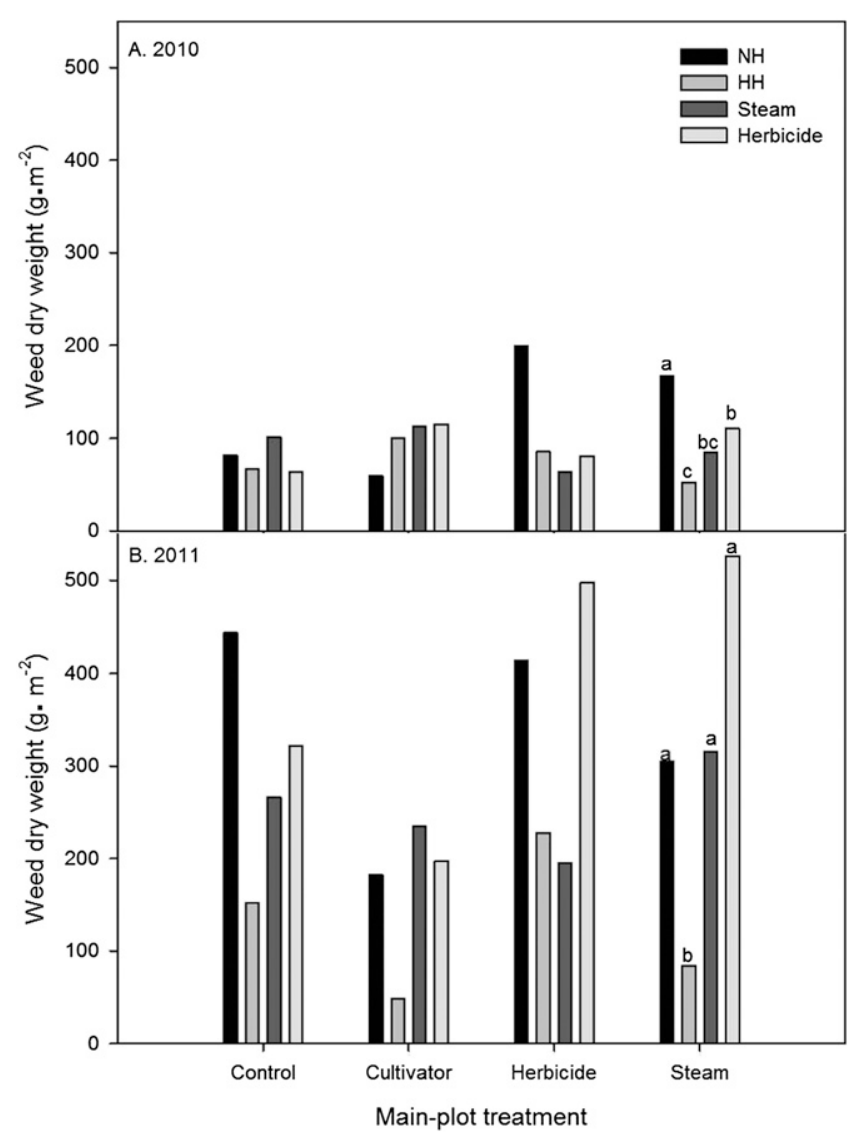

Fig. 2. Aboveground weed dry weight at the second sampling dates (Table 1 ) in the various treatments in (A) 2010 and (B) 2011 in the wine grape vineyards in the southern San Joaquin Valley of California. Bars with the same letter within a main plot are not significantly different according to Fisher's protected least significant difference test at $\alpha=\mathbf{0 . 0 5}$. Analysis was conducted on $\log 10$ transformed data. Cultivator $=$ Bezzerides tree and vine weeder (Bezzerides Brothers, Orosi, CA), plow $=$ French plow $($ L\&H Manufacturing, Selma, CA $)$, herbicide $=[\mathrm{d}$-limonene $\left(\right.$ GreenMatch $^{\circledR} ;$ Marrone Bio Innovations, Davis, CA)], steam = plots treated with the steaming machine (Batchen Stinger; D.J. Batchen, Auburn, Australia); $1 \mathrm{~g} \cdot \mathrm{m}^{-2}=$ $0.0033 \mathrm{oz} / \mathrm{ft}^{2}$.

season (Table 1), no interactions occurred between the years and main or subplot treatments in the raisin or wine grape vineyards. However, in both vineyard types, interactions occurred between main- and subplot treatments. Therefore, data were combined for years but analyzed separately for main plots (Figs. 3 and 4 ). As in the previous sampling date, in the raisin grape vineyards, the success of both the mechanical weed control treatments in reducing weed biomass remained evident, but the other main-plot treatments were no longer effective (Fig. 3). The hoed subplots had lower weed biomass than nonhoed plots, regardless of main-plot treatment (Fig. 3). However, the weed biomass in the control plots that were hoed was greater of yellow nutsedge (data not shown).

\section{Vine growth and canopy characteristic assessments}

The vine physiology, growth, nutrient concentration, and canopy characteristics assessed in this experiment were not influenced by any weed control treatments in either the raisin grape or wine grape vineyards. There were no treatment effects or main plot by subplot interaction effects on midday leaf $\Psi$ at any of the sampling dates at any of the vineyards. The data suggest that the vines experienced low to moderate water stress $(-8.31$ to $-9.42 \mathrm{MPa}$, and -5.15 to $-10.00 \mathrm{MPa}$ in raisin vineyards in 2010 and 2011 , respectively; -9.14 to $-11.97 \mathrm{MPa}$ and -7.65 to -11.97 $\mathrm{MPa}$ in wine grape vineyard in 2010 and 2011, respectively) and the presence of weeds did not cause additional water stress. This finding is interesting as one of the major reasons for not growing cover crops under the vine in the SJV is competition for water by the cover crops. Further, petiole $\mathrm{NO}_{3}$ concentration at bloom time was unaffected by any of the weed control treatments either. The average petiole $\mathrm{NO}_{3}$ concentration ranged from 615 to $1195 \mathrm{ppm}$ and 650 to $950 \mathrm{ppm}$ in the raisin and wine grape vineyards, respectively. However, different effects may occur in vineyards with different water management regimes, environments, and types of weed species present (Tesic et al., 2007).

The number of leaves and total leaf area per foot of vine shoot, and leaf area of individual leaves was unaffected by any of the treatments. Since the study was conducted in two different raisin grape vineyards with different management practices and since date were not collected several days apart (Table 1 ) in these vineyards, data were analyzed for each vineyard separately. There were no interactions between the main- and subplots for the aforementioned parameters. In the wine grape vineyard, the study was conducted in the same plots and data were collected only a few days apart (Table 1). Therefore, data were analyzed to test for year, year by main plot, year by subplot, and main plot by subplot interactions. As none of these tests were significant, data were combined for the two 


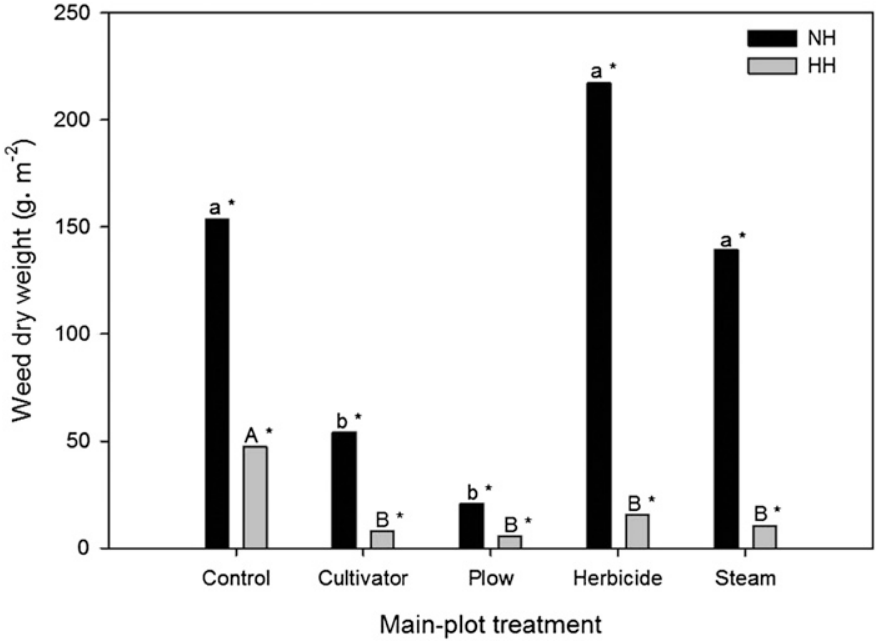

Fig. 3. Aboveground weed dry weight at the final sampling dates (Table 1 ) in the various treatments (average of 2010 and 2011) in the raisin grape vineyards in the southern San Joaquin Valley of California. Bars with the same letter are not significantly different according to Fisher's protected least significant difference test at $\alpha=0.05$. Bars with an asterisk $\left({ }^{*}\right)$ denote significant $(P<0.05)$ difference between the handhoed and non-handhoed subplots within each main-plot treatments. Analysis was conducted on $\log 10$ transformed data. Cultivator $=$ Bezzerides tree and vine weeder (Bezzerides Brothers, Orosi, CA), plow $=$ French plow (L\&H Manufacturing, Selma, CA), herbicide $=\left[\mathrm{d}\right.$-limonene $\left(\right.$ GreenMatch $^{\circledR}$; Marrone Bio Innovations, Davis, CA)], steam = plots treated with the steaming machine (Batchen Stinger; D.J. Batchen, Auburn, Australia); $1 \mathrm{~g} \cdot \mathrm{m}^{-2}=0.0033 \mathrm{oz} / \mathrm{ft}^{2}$.

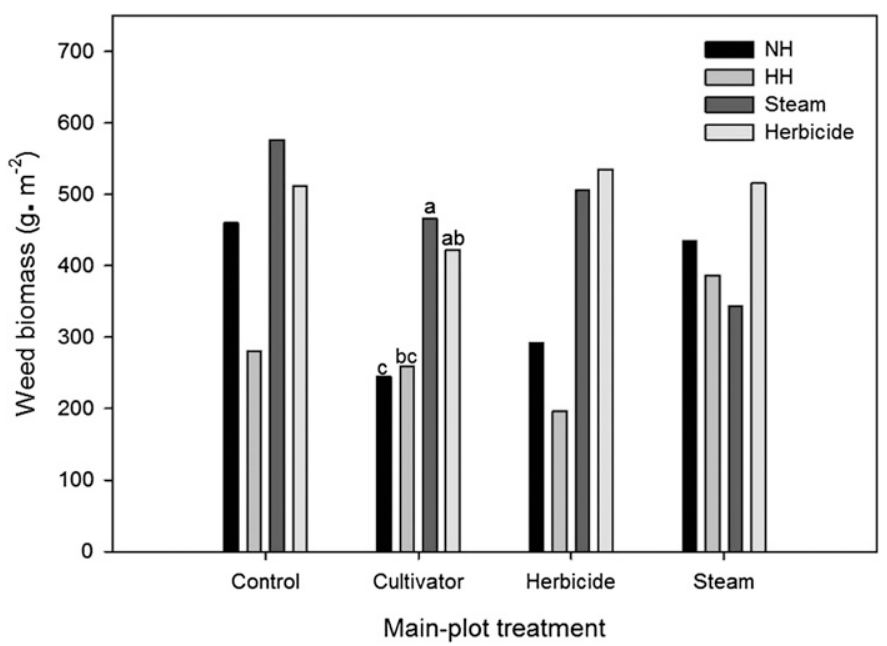

Fig. 4. Aboveground weed dry weight at the final sampling dates (Table 1 ) in the various treatments (average of 2010 and 2011) in the raisin grape vineyards in the southern San Joaquin Valley of California. Bars with the same letter within a main plot are not significantly different according to Fisher's protected least significant difference test at $\alpha=\mathbf{0 . 0 5}$. Analysis was conducted on $\log 10$ transformed data. Cultivator $=$ Bezzerides tree and vine weeder (Bezzerides Brothers, Orosi, CA), plow $=$ French plow $($ L\&H Manufacturing, Selma, CA $)$, herbicide $=[$ d-limonene $\left(\right.$ GreenMatch $^{\circledR} ;$ Marrone Bio Innovations, Davis, CA) $]$, steam = plots treated with the steaming machine (Batchen Stinger; D.J. Batchen, Auburn, Australia); $1 \mathrm{~g} \cdot \mathrm{m}^{-2}=$ $0.0033 \mathrm{oz} / \mathrm{ft}^{2}$.

years and the main plots. Similar to the raisin grape vineyards, none of the treatments had any effect on the parameters tested (data not shown). These data also show that the weed control treatments did not have an effect on crop canopy parameters.

In the raisin grape vineyard, pruning weights of the vines in each treatment differed between years. The average pruning weight was 3.46 and $9.07 \mathrm{lb} /$ vine in the 2010 and 2011 vineyards, respectively. The pruning weights indicated that the vines were not particularly stressed, and the main plot and the subplot treatments had no effect on the average pruning weights per vine in either year. Also, there was no interaction between year and the main-plot treatments or the main- by subplot treatments.

\section{Yield, yield components, and fruit composition}

The weed control treatments had no effect on raisin yields in either of the raisin grape vineyards (Table 3 ). Likewise, berry soluble solids and raisin quality grades were also unaffected by main and subplot treatments, and there were no interactions affecting these variables. Similarly, yield and yield components in the wine grape vineyard were unaffected by main or subplot treatments or their interactions. Fruit composition was also similar regardless of weed control treatments. These results are consistent with the findings of Baumgartner et al. (2007) who reported that increased weed biomass in some treatment plots compared with plots kept clean with glyphosate had no effect on petiole $\mathrm{NO}_{3}$ concentration, vine growth, and crop yield in a drip-irrigated wine grape vineyard. Similarly, in a study comparing nine vineyard floor weed management strategies in the central coast of California, Tourte et al. (2008) reported that the differences in the level of weed control between the treatments did not affect yield.

\section{Cost analysis of weed control treatments}

Mechanical weed control treatments, particularly the plow, were more cost-effective than the other treatments (Table 4). The treatment costs for steam and herbicide were two and three times more, respectively, than the mechanical treatments in the raisin grape vineyards. Similarly, in the wine grape vineyards, these two treatments cost two and four times more, respectively, than the cultivator. Thus, the mechanical weed control methods were by far the most cost-effective treatments in both vineyards.

These studies show that established raisin and wine grape vineyards can tolerate a certain amount of weed 
Table 3. Effects of main-plot treatments on yield components and fruit composition of raisin and wine grape vineyards in 2010 and 2011 in the southern San Joaquin Valley of California $(n=4)$.

\begin{tabular}{|c|c|c|c|c|c|c|c|c|}
\hline \multirow[b]{2}{*}{ Main-plot treatment ${ }^{\mathrm{z}}$} & \multicolumn{2}{|c|}{ Yield (tons/acre) ${ }^{\mathrm{y}}$} & \multicolumn{2}{|c|}{ TSS $(\%)^{\mathrm{x}}$} & \multicolumn{2}{|c|}{$\mathrm{B}$ and better raisins $(\%)^{\mathrm{w}}$} & \multicolumn{2}{|c|}{ Substandard raisins $(\%)^{\mathrm{w}}$} \\
\hline & 2010 & 2011 & 2010 & 2011 & 2010 & 2011 & 2010 & 2011 \\
\hline \multicolumn{9}{|c|}{ Raisin vineyard (2010 and 2011) } \\
\hline Cultivator & 2.91 & 2.07 & 23.6 & 17.8 & 87.3 & 30.3 & 2.09 & 13.4 \\
\hline Plow & 2.48 & 1.68 & 23.6 & 19.0 & 88.6 & 48.3 & 2.51 & 8.7 \\
\hline Herbicide & 2.61 & 1.88 & 21.1 & 18.6 & 85.0 & 41.8 & 2.50 & 9.6 \\
\hline Main-plot treatment & \multicolumn{2}{|c|}{ Yield (tons/acre) } & \multicolumn{2}{|c|}{ TSS (\%) } & \multicolumn{2}{|c|}{ Juice pH } & \multicolumn{2}{|c|}{$\mathrm{TA}\left(\mathrm{mg} \cdot \mathrm{L}^{-1}\right)^{\mathrm{v}}$} \\
\hline \multicolumn{9}{|c|}{ Wine grape vineyard (mean 2010-11) } \\
\hline Nontreated control & \multicolumn{2}{|c|}{3.99} & \multicolumn{2}{|c|}{22.0} & \multicolumn{2}{|c|}{3.34} & \multicolumn{2}{|c|}{7.20} \\
\hline Cultivator & \multicolumn{2}{|c|}{4.69} & \multicolumn{2}{|c|}{21.5} & \multicolumn{2}{|c|}{3.33} & \multicolumn{2}{|c|}{7.72} \\
\hline
\end{tabular}

${ }^{2}$ Nontreated control $=$ no weed control treatment applied, cultivator $=$ Bezzerides tree and vine weeder $($ Bezzerides Brothers, Orosi, CA $)$, plow $=$ French plow $($ L\&H

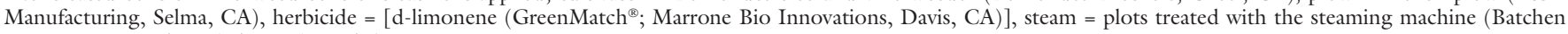
Stinger; D.J. Batchen, Auburn, Australia).

${ }^{\mathrm{y}} 1 \mathrm{ton} / \mathrm{acre}=2.2416 \mathrm{Mg} \cdot \mathrm{ha}^{-1}$.

${ }^{\mathrm{T}} \mathrm{TSS}=$ total soluble solids in juice.

wSubstandard raisins = substandard or undeveloped, B and better raisins = well matured and reasonably well matured raisins.

'TA = titratable acidity measured as milligrams of tartaric acid per liter of juice; $1 \mathrm{mg} \cdot \mathrm{L}^{-1}=1 \mathrm{ppm}$.

Table 4. Operating costs for the various treatments in the raisin and wine grape vineyard experiments in 2010 and 2011 in the southern San Joaquin Valley of California.

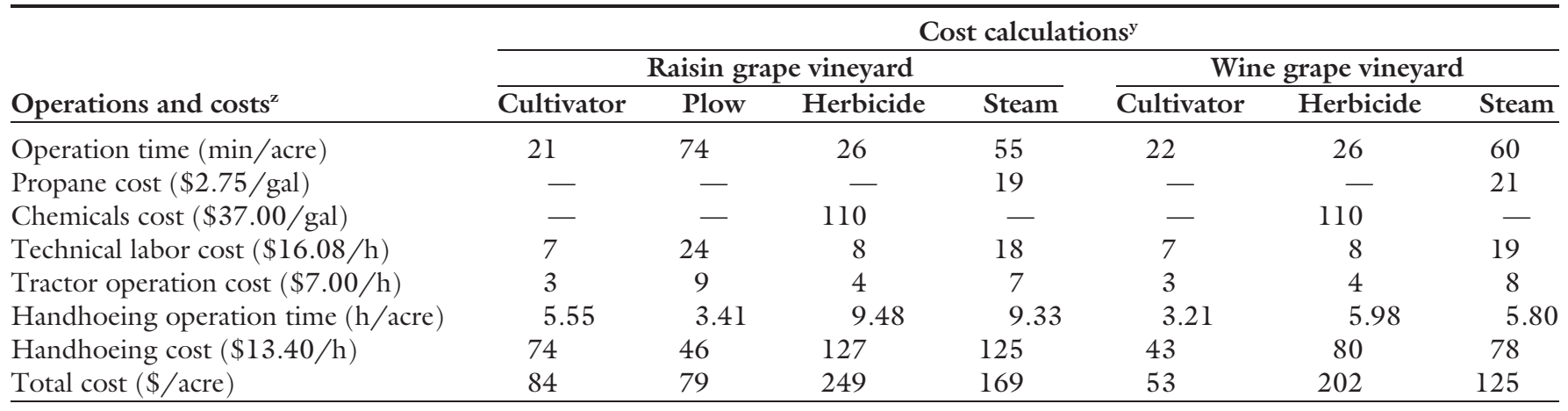

${ }^{\mathrm{z}} 1 \mathrm{~min} / \mathrm{acre}=2.4711 \mathrm{~min} / \mathrm{ha}, \$ 1.00 / \mathrm{gal}=\$ 0.2642 / \mathrm{L}, \mathrm{l} \mathrm{h} / \mathrm{acre}=2.4711 / \mathrm{ha}, \$ 1.00 /$ acre $=\$ 2.4711 / \mathrm{ha}$.

${ }^{y}$ Nontreated control $=$ no weed control treatment applied, cultivator $=$ Bezzerides tree and vine weeder $($ Bezzerides Brothers, Orosi, CA), plow = French plow $($ L\&H Manufacturing, Selma, CA), herbicide $=\left[\mathrm{d}\right.$-limonene $\left(\right.$ GreenMatch $^{\otimes} ;$ Marrone Bio Innovations, Davis, CA $\left.)\right]$, steam $=$ plots treated with the steaming machine $($ Batchen Stinger; D.J. Batchen, Auburn, Australia).

competition without negative effects on yield or quality, a finding that has also been noted by others (Sanguankeo et al., 2009; Shrestha et al., 2010). However, dry weight of one-year-old vines was reduced by upto $81 \%$ when weeds were left uncontrolled compared with a weed-free plot (Bordelon and Weller, 1997). Similar reductions in dry weight and shoot length of grape vines have also been reported by Alcorta et al. (2011) when new grape vine cuttings were planted with a single weed in pot studies conducted in a glasshouse. Therefore, weed control is critical in young vineyards, though established vineyards may be able to tolerate considerable amount of weeds. Nevertheless, weed may have negative indirect effects including harboring pests, creating an environment that may favor certain vine diseases, causing physical hindrances to irrigation systems and other management operations, increasing the risk of frost damage, and reducing the aesthetic quality of vineyards. Mechanical methods may remain the most cost-effective weed management in organic vineyards until more effective and economic methods are developed.

\section{Literature cited}

Alcorta, M., M.W. Fidelibus, K.L. Steenwerth, and A. Shrestha. 2011. Competitive effects of glyphosate-resistant and glyphosate-susceptible Conyza canadensis on young grapevines (Vitis vinifera L.). Weed Sci. 59:489-494.

Ascard, J. 1998. Comparison of flaming and infrared radiation techniques for thermal weed control. Weed Res. 38: 69-76. 
Barberi, P. 2002. Weed management in organic agriculture: Are we addressing the right issues? Weed Res. 42:177-193.

Baumgartner, K., K.L. Steenwerth, and L. Veilleux. 2007. Effects of organic and conventional practices on weed control in a perennial cropping system. Weed Sci. $55: 352-358$.

Bond, W. and A.C. Grundy. 2001. Nonchemical weed management in organic farming systems. Weed Res. 41:383-405.

Bordelon, B.P. and S.C. Weller. 1997. Preplant cover crops affect weed and vine growth in first-year vineyards. HortScience 32:1040-1043.

Capps, S. and W.T. Lanini. 2008. Development in organic herbicides in specialty crops. Proc. 61st Annu. California Weed Sci. Soc. p. 75. (abstr.).

Christensen, P., A.N. Kasimatis, and F.L. Jensen. 1982. Grapevine nutrition and fertilization in the San Joaquin Valley. Univ. California, Div. Agr. Sci., Publ. 4087.

Elmore, C.L., J.A. Roncoroni, L. Wade, and P.S. Verdegaal. 1997. Four weed management systems compared: Mulch plus herbicides effectively control vineyard weeds. Calif. Agr. 51(2):14-18.

Fidelibus, M.W., S.J. Vasquez, and K.A. Cathline. 2007. Canopy separation and defoliation do not improve the dry-onvine (DOV) raisin-making method for 'Thompson Seedless' grapevines on traditional trellises. J. Amer. Pomol. Soc. 61:61-70.

Finney, D.M. and N.G. Creamer. 2008. Weed management on organic farms. North Carolina Coop. Ext. Serv. Publ. No. AG659W-07.

Fredrikson, L., P.A. Skinkis, and E. Peachey. 2011. Cover crop and floor management affect weed coverage and density in an establishing Oregon vineyard. Hort Technology 21:208-216.

Gago, P., C. Cabaleiro, and J. Garcia. 2007. Preliminary study of the effect of soil management systems on the adventitious flora of a vineyard in northwestern Spain. Crop Protection 26:584-591.

Hirschfelt, D.J. 2000. Vineyard floor management, p. 134-138. In: L.P. Christensen (ed.). Raisin production manual. Univ. California, Div. Agr. Natural Resources, Publ. 3393.
Kagawa, Y. 2000. Quality standards and inspection, p. 236-241. In: L.P.Christensen (ed.). Raisin production manual. Univ. California, Agr. Natural Resources, Oakland.

Keller, M., R.P. Smythman, and L.J. Mills. 2008. Interactive effects of deficit irrigation and crop load on Cabernet Sauvignon in an arid climate. Amer. J. Enol. Viticult. 59:221-234.

Klonsky, K. 2010. A look at California's organic agriculture production. Univ. California Giannini Foundation of Agr. Econ. ARE Update 14(2):8-11.

Kolberg, R.L. and L.J. Wiles. 2002. Effect of steam application on cropland weeds. Weed Technol. 16:43-49.

Leon, R.G. and D.T. Ferreira. 2008. Interspecific differences in weed susceptibility to steam injury. Weed Technol. 22: 719-723.

Martini, E.A., J.S. Buyer, D.C. Bryant, T.K. Hartz, and R.F. Denison. 2004. Yield increases during the organic transition: Improving soil quality or increasing experience? Field Crops Res. 86:255266.

McCue, J.J. and J.R. Schupp. 1991. Inrow tilling for orchard weed control. HortScience 26:695. (Abstr.).

Mennan, H. and M. Ngouajio. 2012. Effect of brassica cover crops and hazelnut husk mulch on weed control in hazelnut orchards. HortTechnology 22:99-105.

Ngouajio, M. and M.E. McGiffen. 2002. Going organic changes weed population dynamics. HortTechnology 12:590-596.

Park, T.A. and L. Lohr. 2005. Organic pest management decisions: A systems approach to technology adoption. Agric. Econ. 33:467-478.

Sanguankeo, P.P., R.G. Leon, and J. Malone. 2009. Impact of weed management practices on grapevine growth and yield components. Weed Sci. 57:103107.

Sartorato, I., G. Zanin, C. Baldoin, and C. de Zanche. 2006. Observations on the potential of microwaves for weed control. Weed Res. 46:1-9.

Shrestha, A., D.R. Clements, and M.K. Upadhyaya. 2004. Weed management in agroecosystems: Towards a holistic approach, p. 451-477. In: S.G. Pandalai (ed.). Recent research developments in crop. Science 1 (Part II). Research Signpost, Trivandrum, India.

Shrestha, A., M.W. Fidelibus, M.F. Alcorta, and K. Cathline. 2010. Threshold of horseweed (Conyza canadensis) in an established Thompson Seedless vineyard in the San Joaquin Valley. Intl. J. Fruit Sci. 10:301-308.

Shrestha, A., M. Moretti, and N. Mourad. 2012. Evaluation of thermal implements and organic herbicides for weed control in nonbearing almond (Prunus dulcis) orchard. Weed Technol. 26:110-116.

Smart, R.E. 1985. Principles of grapevine canopy microclimate manipulation for yield and quality. A review. Amer. J. Enol. Viticult. 36:230-289.

Smith, R.G., R. Jabbour, A.G. Hulting, M.E. Barbercheck, and D.A. Mortensen. 2009. Effects of initial seed-bank density on weed seedling emergence during the transition to an organic feed-grain crop rotation. Weed Sci. 57:533-540.

Steinmaus, S., C.L. Elmore, R.J. Smith, D. Donaldson, E.A. Weber, J.A. Roncoroni, and P.R.M. Miller. 2008. Mulched cover crops as alternative to conventional weed management systems in vineyards. Weed Res. 48:273-281.

Terry, D.B. and S.K. Kurtural. 2011. Achieving vine balance of Syrah with mechanical canopy management and regulated deficit irrigation. Amer. J. Enol. Viticult. 62:426-437.

Tesic, D., M. Keller, and R.J. Hutton. 2007. Influence of vineyard floor management practices on grapevine vegetative growth, yield, and fruit composition. Amer. J. Enol. Viticult. 58:1-11.

Tourte, L., R. Smith, L.J. Bettiga, T. Bensen, J. Smith, and D. Salm. 2008. Post-emergence herbicides are cost effective for vineyard floor management in the Central Coast. Calif. Agr. 62(1):19-23.

Ulloa, S.M., A. Datta, and S.Z. Knezevic. 2010. Growth stage-influenced differential response of foxtail and pigweed species to broadcast flaming. Weed Technol. 24:319-325.

Verdegaal, P.S., K.M. Klonsky, and R.L. De Moura. 2012. Sample costs to establish a vineyard and produce winegrapes. Univ. California Coop. Ext., Davis. 